\title{
Germination of Coreopsis lanceolata and Echinacea purpurea Seeds following Priming and Storage
}

\author{
Dina Margaret Samfield', Jayne M. Zajicek ${ }^{2}$, and B. Greg Cobb ${ }^{3}$ \\ Department of Horticultural Sciences, Texas A\&M University, College \\ Station, TX 77843-2123
}

Additional index words. osmoconditioning, wildflowers

\begin{abstract}
Seeds of tickseed (Coreopsis lanceolata $\mathbf{L}$.) and purple coneflower [Echinacea purpureo (L.) Moench] were primed in aerated solutions of a $50 \mathrm{mM}$ potassium phosphate buffer at 16C. C. lanceolata seeds were primed for 3 or 6 days; E. purpurea seeds were primed for 6 or 9 days. Seeds were vacuum-stored for 2 months immediately after priming. Identical treatments were imposed on open-stored seeds just before the termination of the storage duration, thus producing four treatments: a vacuum-stored control, an open-stored control, primed vacuum-stored seed, and seed primed after open storage. Although priming significantly improved the performance of C. lanceolata seed, vacuum storage alone also significantly increased the speed of germination and final germination. The advantage of priming was diminished during 2 months of vacuum storage of $E$. purpurea, but priming enhanced germination as compared with the open-stored nonprimed control. There was little difference between the performance of $E$. purpurea seeds both primed and vacuum-stored. and the vacuum-stored control.
\end{abstract}

Tickseed and purple coneflower, both Asteraceae, are native Texas wildflower species that display great potential for use in urban landscapes. However, they display undesirable germination characteristics such as delayed germination and wide variation in emergence rate that reduce the uniformity of seedling stands (Atwater, 1980).

These limitations to seed propagation of Asteraceae species are attributable, at least partly, to a semi-permeable inner membranous seed coat that may restrict the passage of water and oxygen to the embryo and prevent leaching of inhibitors found in the cotyledons (Atwater, 1980; Wareing and Saunders, 1971). General recommendations 10 improve germination of $C$. lanceolata seed include a presoak in water followed by a soak in $0.2 \% \mathrm{KNO}_{3}$ and germination at $15 \mathrm{C}$ for 40 days (Atwater, 1980). Germination procedures for $E$. purpurea include moist stratification at 19 to $24 \mathrm{C}$ for 4 weeks before planting (Phillips, 1985). However, osmoconditioning, or seed priming, may be a more effective and efficient presowing treatment for the production of more uniform seedling stands.

Storage for up to 28 days of primed tomato and carrot seeds, dried after priming, has been shown 10 have no effect on the

Received for publication 9 Jan. 1989. Texas Agricultural Experiment Journal Article no. 24549. Use of a company or product name does not imply approval or recommendation of the product to the exclusion of others that may also be suitable. The cost of publishing this paper was defrayed in part by the payment of page charges. Under postal reg ulations, this paper therefore must be hereby marked advertisement solely to indicate this fact.

${ }^{1}$ Graduate student.

${ }^{2}$ Assistant professor.

${ }^{3}$ Associate professor. priming response of these seeds (Haigh et al., 1986). Primed watermelon seeds have been dried after treatment and stored for up to 20 weeks and still maintained the advantageous effects of priming (Sachs, 1977).

Several studies on herbaceous ornamental seed have indicated that sealed storage is a more effective means of maintaining seed viability than open storage (Barton, 1960; Bass, 1980; Bass et al., 1962; Harrington, 1973). Seed priming in combination with sealed, dry storage would appear to provide the best possible treatment for the enhancement of commercial flower seed performance. In a previous study of $C$. lanceolata and $E$. purpurea, osmoconditioning significantly enhanced the earliness and uniformity of both seed germination and seedling emergence (Samfield et al., 1990). The most beneficial results were achieved when the seeds were primed in aerated solutions of distilled water or a 50-mM potassium phosphate buffer. The most effective durations of treatment were 3 and 6 days for C. lanceolata and 6 and 9 days for E. purpurea. This study examined the effects of priming coupled with vacuum storage on the germination response of $C$. lanceolata and E. purpurea.

Seeds of Echinacea purpurea and Coreopsis lanceolata (donated by Wildseed, Inc., Houston, Texas) were tested before they were primed to assess storage effects at termination of the study. Seeds of $C$. lanceolata were primed for 3 or 6 days and seeds of $E$. purpurea for 6 or 9 days in 1-liter, aerated solutions of a $50-\mathrm{mm}$ potassium phosphate buffer $\left(\mathrm{KH}_{2} \mathrm{PO}_{4}+\mathrm{K}_{2} \mathrm{HPO}_{4}\right)(\mathrm{pH}$ 7.0) held at $16 \pm 1 \mathrm{C}$. The solutions were saturated with air circulated through plastic tubing connected to two 115-V PennPlax (Penn-Plax Plastic, Garden City, N.Y.) aquarium air pumps. After priming, the seeds were rinsed thoroughly in distilled water and air-dried for $24 \mathrm{hr}$, which returned the seeds to their original moisture content of $12 \%$. Controls were the untreated seed of each species. Control and primed seeds were vacuum-stored for 2 months at $12 \mathrm{C}$ in tin-plated, enamel-lined cans sealed with a semi-automatic vacuum closing machine. Another group of seeds was not vacuum-stored, but was open-stored at $50 \% \mathrm{RH}$ and $12 \mathrm{C}$ in vapor-permeable cloth bags. Identical treatments were imposed on open-stored seeds just before the termination of storage, thus producing four treatments: a vacuum-stored control, an open-stored control, primed vacuum-stored seed, and seed primed after open storage.

Germination tests were carried out in darkness in temperature-controlled incubators held at $23 \pm 1 \mathrm{C}$. Seeds were placed on two layers of moistened (Whatman \#1) filter paper in covered $5.5-\mathrm{cm}$ petri dishes. Each dish contained 50 seeds, with three replicate dishes per treatment. Radicle protrusion to 1 $\mathrm{mm}$ was scored as germination. Seed germination was recorded at 24-hr intervals for 14 days. The mean time to germination was calculated from the equation: $T_{S 0}=\Sigma T_{i} N_{1} /$ $\mathrm{IN}$, where $\mathrm{N}$, is the number of newly germinated seeds at time $\mathrm{T}_{\mathrm{i}}$ (Alvarado et al., 1987). The experimental design was a $2 \times$ 3 factorial. An analysis of variance was conducted and, where appropriate, mean separation determined by a $t$ test or by Dunnett's. In the case of an interaction, linear and quadratic contrasts were carried out.

Seed of both species germinated about equally well before open-storage and at its termination, indicating no natural decline of germination (data not shown).

C. lanceolata. Regardless of the duration of priming, the seeds that had been vacuumstored for 2 months before sowing germinated significantly faster and at a higher per-

Table 1. Effect of 2 months of vacuum storage on percent germinalion of Coreopsis lanceolata seed.

\begin{tabular}{lcr}
\hline \hline $\begin{array}{l}\text { Days from } \\
\text { sowing }\end{array}$ & \multicolumn{2}{c}{ Germination $\left(\mathcal{F}^{*}\right)^{2}$} \\
\cline { 2 - 3 } & $\begin{array}{c}\text { Vacuum- } \\
\text { slored }\end{array}$ & $\begin{array}{r}\text { Open- } \\
\text { slored }^{x}\end{array}$ \\
\hline 2 & 0.9 & 0.4 \\
4 & 6.7 & 4.7 \\
6 & $22.7^{*}$ & 10.4 \\
8 & $30.2^{*}$ & 15.3 \\
10 & $36.0^{*}$ & 20.7 \\
12 & $42.4^{*}$ & 24.2 \\
14 & $45.5^{*}$ & 26.9 \\
\hline
\end{tabular}

${ }^{\mathrm{z}}$ Mean separation in rows by $t$ test, $P=0.001$ (*).

${ }^{\mathrm{y}}$ Vacuum-stored seed was primed and stored for 2 months at $12 \mathrm{C}$ in tin-plated, enamel-lined cans. Data pooled over primed treatments (three replications of 50 seeds each per treatment) including a control (nonprimed seed) and seed primed in 50 $\mathrm{mM} \mathrm{K}_{2} \mathrm{HPO}_{4}+\mathrm{KH}_{2} \mathrm{PO}_{4}$ for 3 or 6 days.

${ }^{x}$ Open-stored seed was stored at $50 \% \mathrm{RH}$ and $12 \mathrm{C}$ in vapor-permeable cloth bags. Seeds were primed after removal from storage. Data pooled over primed treatments (three replications of 50 seeds each per treatment) including a control (nonprimed seeds and seed primed in $50 \mathrm{mM} \mathrm{K} \mathrm{KPO}_{4}+\mathrm{KH}_{2} \mathrm{PO}_{4}$ for 3 or 6 days. 
Table 2. Effect of duration of priming on percent germination of Coreopsis lanceolata seed.

\begin{tabular}{lrrr}
\hline & \multicolumn{3}{c}{ Germination $\left(\%^{2}\right)^{z}$} \\
\cline { 2 - 4 } $\begin{array}{l}\text { Days from } \\
\text { sowing }\end{array}$ & \multicolumn{3}{c}{ Priming duration (days)y } \\
\cline { 2 - 4 } & 0 & \multicolumn{1}{c}{3} & 6 \\
\hline 2 & 0.0 & 1.0 & 1.0 \\
4 & 2.3 & $7.7^{*}$ & $7.0^{*}$ \\
6 & 11.3 & $21.3^{*}$ & $17.0^{*}$ \\
8 & 17.0 & $28.7^{*}$ & $22.7^{*}$ \\
10 & 23.0 & $34.0^{*}$ & $28.0^{*}$ \\
12 & 29.3 & $38.0^{*}$ & 32.7 \\
14 & 33.0 & $42.0^{*}$ & 33.7 \\
\hline
\end{tabular}

${ }^{\mathrm{z}}$ Mean separation in rows between control ( 0 days $)$ and treatments by Dunnctt's test, $\mathrm{P}=0.01(*)$.

${ }^{y}$ Data pooled over storage treatments per treatment duration (three replications of 50 seeds each per treatment) including a control (nonprimed seed) and seed primed in $50 \mathrm{mM} \mathrm{K}_{2} \mathrm{HPO}_{4}+\mathrm{KH}_{2} \mathrm{PO}_{4}$ vacuum-stored for 2 months at $12 \mathrm{C}$, and openstored seed nonprimed or primed in $50 \mathrm{mM} \mathrm{K}_{2} \mathrm{HPO}_{4}$ $+\mathrm{KH}_{2} \mathrm{PO}_{4}$.

centage than those that were not vacuumstored (Table 1). As germination increased, this relationship between the vacuum- and open-stored seeds remained relatively constant. By day 14, the seeds that were openstored had achieved only $59 \%$ of the level of germination of the vacuum-stored seeds. In addition, seeds that were open-stored had an average $T_{50}$ of 8.1 days, whereas the $T_{50}$ of vacuum-stored seeds was 7.3 days.

The duration of priming also significantly affected $C$. lanceolata germination (Table 2). Seeds primed for 3 days maintained significantly higher germination percentages than nonprimed seeds between days 4 and 14 of the experiment. Seeds primed 6 days reached a higher percentage of germination than the controls from days 4 through 10 , but thereafter germinated similarly as the controls. In addition, priming for 3 and 6 days reduced $\mathrm{T}_{50}$ by 1.2 and 1.7 days, respectively. $\mathrm{T}_{50}$ for nonprimed seeds (vacuum- and openstored) was 8.4 days.

E. purpurea. The interaction between the effects of storage and duration of priming was highly significant for E. purpurea (Table 3). In general, seeds that were open-stored and then primed achieved the highest germination percentages and germinated most rapidly. Open-stored seeds primed for 6 and 9 days reduced $\mathrm{T}_{50}$ by 5 and 5.2 days, respectively, compared with the open-stored control. Seeds of the identical vacuum-stored treatments reduced $\mathrm{T}_{50}$ by 3.3 and 3.1 days, and vacuum-stored control seeds decreased $\mathrm{T}_{50}$ by 2 days compared with the open-stored control.

Whereas vacuum storage generally increased the germination response of Coreopsis, the advantageous effects of priming were diminished during vacuum storage of $E$. purpurea. For this species, seeds primed immediately before sowing exhibited the best germination response, including a significantly reduced $\mathrm{T}_{50}$. There appeared to be little difference in the performance of seeds primed before storage and those vacuumstored but not primed. The $\mathrm{T}_{50}$ of those primed before storage was significantly reduced in comparison to that of the vacuum-stored control seeds, however. These results are similar to a recent study conducted on tomato seed in which a low-temperature priming treatment applied before seed aging significantly slowed seed deterioration (Francis and Coolbear, 1988). They determined that priming before storage restores or protects $\mathrm{T}_{50}$.

Our data suggest that storing the seed of both species at a low moisture level under a

Table 3. Interactive effects of vacuum storage and duration of priming on percent germination of Echinacea purpurea seed.

\begin{tabular}{|c|c|c|c|c|c|c|c|}
\hline \multirow{3}{*}{$\begin{array}{l}\text { Priming } \\
\text { duration } \\
\text { (days) }\end{array}$} & \multicolumn{7}{|c|}{ Germination $(\%)$} \\
\hline & \multicolumn{7}{|c|}{ Days from sowing } \\
\hline & 2 & 4 & 6 & 8 & 10 & 12 & 14 \\
\hline \multicolumn{8}{|c|}{ Vacuum-stored ${ }^{2}$} \\
\hline 0 & 0.0 & 4.7 & 36.0 & 54.3 & 65.3 & 74.0 & 77.3 \\
\hline 6 & 1.3 & 24.0 & 40.0 & 51.3 & 58.0 & 59.3 & 62.0 \\
\hline 9 & 0.0 & 20.0 & 45.3 & 63.3 & 70.0 & 72.0 & 74.3 \\
\hline Linear & NS & • & NS & NS & NS & NS & NS \\
\hline Quadraric & NS & NS & vs & ins & NS & NS & NS \\
\hline \multicolumn{8}{|l|}{ Open-storedy } \\
\hline 0 & 0.0 & 0.0 & 9.3 & 20.7 & 28.0 & 40.7 & 47.3 \\
\hline 6 & 6.7 & 57.3 & 82.3 & 87.3 & 89.3 & 90.7 & 92.0 \\
\hline 9 & 6.0 & 54.0 & 75.3 & 80.0 & 82.7 & 82.7 & 82.7 \\
\hline Linear & ** & $\cdots$ & $\cdots *$ & $\cdots$ & $=$ & "* & $*$ \\
\hline Quadratic & $\cdot$ & $* * *$ & $\cdots$ & $* *$ & $*$ & $*$ & 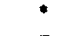 \\
\hline
\end{tabular}

${ }^{\mathrm{z}}$ Vacuum-stored seed was primed in $50 \mathrm{mM} \mathrm{K} \mathrm{HPO}_{4}+\mathrm{KH}_{2} \mathrm{PO}_{4}$ for 6 or 9 days or not primed (controls) and stored for 2 months at $12 \mathrm{C}$ in tin-plated, enamel-lined cans (three replications of 50 seeds each per treatment).

${ }^{y}$ Open-stored seed was stored at $50 \% \mathrm{RH}$ and $12 \mathrm{C}$, then primed in $50 \mathrm{mM} \mathrm{K} \mathrm{K}_{2} \mathrm{HPO}_{4}+\mathrm{KH}_{2} \mathrm{PO}_{4}$ for 6 or 9 days or not primed (control) (three replications of 50 seeds each per treatment).

NS ,***,***Nonsignificant or significant at $P=0.05,0.01$, or 0.001 , respectively, via $\mathrm{F}$ test.

partial vacuum improved the performance of the seed as well as did seed priming compared to open-stored, nonprimed seed. Although seed moisture content and storage temperature are generally considered to be more important than the composition of the surrounding atmosphere in affecting seed longevity (Bass, 1978), seeds stored in sealed containers retained 'their germination better than those stored in open containers according to other studies (Barton, 1953; Bass, 1978, 1980). In addition, any storage condition that reduces respiratory activity tends to prolong seed viability (Milner and Geddes, 1954). Therefore, adequate drying followed by sealed storage in limited oxygen environments probably constitutes optimum conditions for most seeds that endure drying (Bass et al., 1962).

\section{Literature Cited}

Alvarado, A.D., K.J. Bradford, and J.P. Hewitt. 1987. Osmotic priming of tomato seeds: Effects on germination, field emergence, seedling growth, and fruit yield. J. Amer. Soc. Hort. Sci. 112(3):427-432.

Atwater, B.R. 1980. Germination, dormancy and morphology of the seeds of herbaceous ornamental plants. Seed Sci. Technol. 8:523-573.

Barton, L.V. 1953. Seed storage and viability. Contrib. Boyce Thompson Inst. 17:87-103.

Barton, L.V. 1960. Storage of seeds of Lobelia cardinalis L. Contrib. Boyce Thompson Inst. 20:395-401.

Bass, L.N. 1978. Sealed storage of crimson clover seed. Seed Sci. Tcchnol. 6:1017-1024.

Bass, L.N. 1980. Flower seed storage. Seed Sci. Technol. 8:591-599.

Bass, L.N., D.C. Clark, and E. James. 1962. Vacuum and inert-gas storage of lertuce seed. Proc. Assn. Offic. Seed Anal. 52:116-122.

Francis, A. and P. Coolbear. 1988. Changes in the fatty acid content of the polar lipid fraction of tomato seeds induced by ageing and/or subsequent low temperature presowing treatment. Seed Sci. Technol. 16:87-95.

Haigh, A.M., E.W.R. Barlow, and F.L. Milthorpe. 1986. Field emergence in tomato, carrot, and onion seeds primed in aerated salt solution. J. Amer. Soc. Hort. Sci. 111(5):660665.

Harrington, J.F. 1973. Packaging seed for storage and shipment. Seed Sci. Technol. 1:701-709.

Milner, M. and W.F. Geddes. 1954. Respiration and heating, p. 152-220. In: J.A. Anderson and A.W. Alcock (eds.). Storage of cereal grains and their products. Amer. Assn. Cereal Chemists, St. Paul, Minn.

Phillips, H.R. 1935. Growing and propagating wild flowers. Univ. N. Carolina Press, Chapel Hill.

Sachs, Menachem. 1977. Priming of watermelon seeds for low-temperature germination. J. Amer. Soc. Hort. Sci. 102(2):175-178.

Samfield, D.M., J.M. Zajicek, and B.C. Cobb. 1990. Rate and uniformity of herbaceous perennial seed germination and emergence as affected by osmoconditioning. J. Amer. Soc. Hort. Sci. (In press.)

Wareing, P.E. and P.R. Saunders. 1971. Hormones and dormancy. Annu. Rev. Plant Physiol. 22:261-288. 